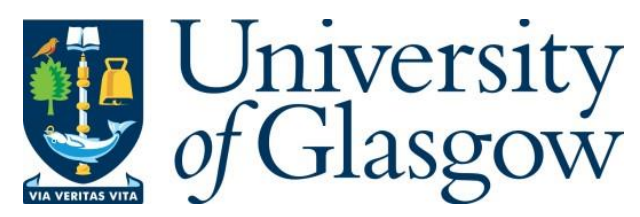

Bernard, S. (2019) Oil shocks, migration and European integration: a (Trans)national perspective on the Yugoslav crises of the 1980s. National Identities, 21(5), pp. 463-484. (doi:10.1080/14608944.2018.1498471)

There may be differences between this version and the published version. You are advised to consult the publisher's version if you wish to cite from it.

http://eprints.gla.ac.uk/165199/

Deposited on: 17 July 2018

Enlighten - Research publications by members of the University of Glasgow http://eprints.gla.ac.uk 


\title{
Oil shocks, migration and European integration: A (trans)national perspective on the Yugoslav crises of the 1980s
}

\author{
Sara Bernard, University of Glasgow \\ Sara.Bernard@glasgow.ac.uk
}

\begin{abstract}
The extensive Yugoslav economic migration and presence of Yugoslav ethnic minorities in Western Europe, as well as the interaction of this migration with the Yugoslav crisis of the 1980s, remain under-researched. This article sets out to offer a modest contribution on this neglected topic. It argues that short-distance transnational communities and short-term migration were already at the centre of grievances articulated on ethno-nationalist grounds in the early 1980s. It links these grievances to the different impact of the two oil shocks and the process of European integration on each Yugoslav republic, differences which contributed to the crisis of federal unity.
\end{abstract}

Keywords Yugoslav 1980s crisis; oil shocks; Yugoslav economic migration; EEC migration policies; Slovenian nationalism; Alp-Adria region

Word count: 8321 


\section{Introduction}

Yugoslavia underwent a deep economic crisis in the early 1980s that would develop into a systemic crisis in the second half of the decade. Despite this protracted period of difficulties, however, the literature investigating the reasons for the collapse of Yugoslavia and the wars of the 1990s has largely focused only on the second half of the 1980s. Moreover, it emphasised the ethno-nationalist drift more than the political divisions between republics over strategies to exit the economic crisis that emerged in the early 1980s. The academic debate generally attributes the development of irreconcilable positions in the Yugoslav federal assembly to the rise and ultimate success of ethno-nationalist rhetoric among the political and cultural elites of the country's republics from the second half of the 1980s. There is a broad consensus in the scholarship, for example, that the rise to power of Slobodan Milošević in 1987 was a major turning point in the unmaking of federal relations - a turning point that opened the gateway to the Slovenian declaration of independence, which was followed by the ten-day war between the Yugoslav federal army and the Slovenian Territorial Defence (27 June- 6 July 1991), and the wars in Bosnia-Herzegovina and Croatia (19921995) and Kosovo (1999). (Baker, 2015, pp. 35-39; Ramet, 1999, Chapter 1, 2005, Chapter 7). Studies that discuss the Yugoslav collapse by looking primarily at actors that, from abroad, influenced and interacted with Yugoslav domestic dynamics stress that Western powers and institutions were too cautious and late to intervene against the expansionist aims of the Serbian and the Croatian leadership towards Bosnia-Herzegovina. (Ramet, 2005, Chapter 4; Glaurdić, 2011; Shoup, 2008; Baker, 2015, 66-77, and Chapter 6). ${ }^{\mathrm{i}}$ Scholars have also examined the role of diaspora communities in the collapse of Yugoslavia. They have shown how the leaders of the Yugoslav republics and their co-ethnic communities abroad strengthened transnational ties from the late 1980s. These ties were important for gathering financial and media support for ethno-nationalist explanations and solutions to the 
deteriorating status quo (Skrbiš, 1999; Hockenos, 2003; Ragazzi, 2009; Bock-Luna, 2007; Radeljić, 2012, Chapter 4).

The purpose of this article is to explore in greater depth how domestic and external actors and factors interacted in the Yugoslav crisis of the 1980s. It does so by focusing on migration. Unlike existing studies, however, this article does not set out to investigate ethno-nationalisms in Yugoslavia as they developed in the late stages of the crisis in the second half of the 1980s. Instead, it concentrates on the economic crisis of the first half of that decade. Rather than examining long-distance nationalism and diaspora support for alternatives to the Yugoslav federal and socialist project, the article shows that short-distance transnational communities and short-term migration were already at the centre of grievances articulated on ethnonationalist grounds in the early 1980s. It endeavours to prove this by showing that the consequences of the two oil shocks, in 1973 and 1979 respectively, and the advancement of European integration, had two major effects. First, they resulted in changes in the international mobility of Yugoslav migrants towards western European countries. Second, they changed relations between Yugoslav and hosting countries' state authorities on the one hand and Yugoslavs living in those countries on the other hand. These two changes affected the six Yugoslav republics in different ways that, this article will argue, served to exacerbate pre-existing socio-economic regional disparities, which were themselves the reason for political divisions between the Yugoslav republics. These changes therefore contributed to the crisis of federal unity during the 1980s.

Moreover, this article shows that the crisis of Yugoslav domestic cooperation occurred in close connection with broader changes in the European and Cold War equilibriums. The article underlines the causative role of international migration in Western Europe $\mathrm{i}^{\mathrm{ii}}$ in this process. In particular, the article draws attention to the fact that the approach towards international migration changed between the mid-1970s and the mid-1980s in the western 
European hosting countries. From accepting international migration as a factor promoting economic cooperation and European integration in the aftermath of the first oil shock, the approach changed in the aftermath of the second oil shock to implementing a dual system of migration. This now linked freedom of movement of labour to EEC membership on the one hand, and the creation of new restrictions on non-EEC members on the other. Given the inclusion of countries lying on the northern bank of the Mediterranean Sea (Greece, Spain, Portugal) in the EEC, the effect was to shut out the south Mediterranean (Turkey and Maghreb).

The article shows that socialist Yugoslavia, which, like other Mediterranean sending countries, exported its labour force to Western Europe, was affected by these changes in a particular way. The article explains that Yugoslav migration patterns towards Western Europe varied by region, reflecting the different relations that each Yugoslav republic maintained with Western Europe. The republics' different relations with Western Europe constituted one of the main factors determining their different levels of development and of integration in the world economy, both of which were key in shaping the republics' various responses to the Yugoslav economic and political crisis of the 1980s. These differences also meant in turn that the changes in the regulation of international migration in Western Europe affected Yugoslav migrants and their regions of provenance in different ways.

To prove its case this article focuses on Slovenia. The rationale for this focus is partly that Slovenia's geographic proximity and historical legacyiii meant it had developed strong ties with neighbouring European countries and was involved earlier than other Yugoslav regions in labour migration towards Western Europe. As the most developed Yugoslav republic, moreover, Slovenia was to be a key actor during the debt crisis of the 1980s. The republic's favourable economic condition was also the reason why workers from other Yugoslav republics migrated to Slovenia in search of employment, especially at times when job 
opportunities became less available in the domestic market or overseas. In addition, Slovenia was directly involved in territorial contentions between Yugoslavia and neighbouring Italy and Austria, due to the presence of Slovenian ethnic minorities living in the contested areas of these countries adjoining the Slovenian border. Accordingly, the argument is not that Slovenia was the republic most affected by emigration. It is also not the case that its leadership explained emigration of its nationals as a consequence of exploitation by other republics. This might have been the case with Croatia and, eventually, Serbia (Zimmerman, 1987, pp. 125, 126). Nonetheless, this article argues that Slovenian relations with Western Europe and the migrations they generated contributed to forging Slovenian ethno-national identity, and the republic's path to independence, even before the aggressive Serbian leadership drive to recentralise Yugoslavia in the late 1980s.

The article shows that, in the early 1980s, migration became a vehicle for the legitimisation of narratives according to which the Yugoslav federation was an artificial construct and a threat to a distinctly Slovene national character. This article maintains that macro-economic and geostrategic changes occurring in the broader European region and the migration regimes these changes supported were in part responsible for this shift in Slovenia. More precisely, the article examines how the two oil shocks of the 1970s and the process of European integration increased return migration to Yugoslavia and thereby also domestic labour immigration to Slovenia, as returning workers found more opportunities in that republic than their home republics. Anti-immigrant feeling in Slovenia increased substantially in these years, facilitating the growth of new notions of Slovene identity as being radically separate from Yugoslav identity. Furthermore, the process of European regional integration, through the Alp-Adria community, an EEC project including Austrian, Croatian, Italian and Slovene regions, also strengthened ideas of Slovene separateness among Slovenes living outside Slovenia. The notion of Slovene 'Europeanness' also found a hearing in Catholic circles in 
Austrian and Italian Alp-Adria regions, solidifying new transnational networks that would help later campaigns for Western recognition of Slovene secession.

To support this argument, the article relies on key studies on migration policies and patterns in Yugoslavia and Western European countries, as well as studies on Yugoslav international relations. It also draws on statistical data and evidence from the Yugoslav press and state political archives. Finally, it employs the collection of relevant documents produced by EC bodies on Yugoslav-EEC relations and edited by Branislav Radeljić (2017).

Labour migration, economic cooperation and European integration in the second half of the 1970 - and changes in the 1980s

The argument in this article begins by locating Yugoslavia in the overall changes affecting Europe in the period from the early 1970s to the early 1980s. The first and second oil shocks and the advancement of European integration led to substantial changes in relations between the southern and north-west European countries. These changes had a direct effect on the regulation of labour immigration from Mediterranean to north-west European countries. Since the very beginning of the process of European integration, the gradual introduction of free movement of labour had been considered instrumental in promoting economic development and peaceful intra-state relations among Western European countries (Comte, 2012, 2018; Tapinos, 2000). Italy, the only emigration country among the EEC founding members, was the first and principal beneficiary of this approach. Nonetheless, in the years of economic boom in Europe from 1945 to 1971, labour migrants from non-EEC countries were also recruited on a large scale, through intra-state bilateral agreements that established short-term contracts and foresaw the eventual return of these migrant workers to their countries of origin (Hansen, 2003). 
The first oil shock put an end to intra-state agreements for the recruitment of foreign labour. By 1975, policies to favour return migration were introduced instead. The OECD sponsored negotiations between sending and hosting countries, which aimed to create work places in emigration areas, creating a network of experts and legal/economic advisors to help hosting and sending countries in their investment projects in emigration areas. One of these forms of cooperation consisted in the outsourcing of European enterprises where employment would thus be offered for returnees and the local labour force (Tapinos, 2000, p. 300). The expectation was that this form of economic cooperation would lead to the development of emigration areas and gradually eliminate the reasons for emigration. At the same time, the social rights of migrant workers residing in Western Europe improved thanks to negotiations within the Helsinki Summit held in 1975 (Kubat, 1993, pp. xi-xv; Petković, 1988, pp. 324352). Foreign citizens with a valid working permit and several years of legal and uninterrupted presence in the hosting country were given the possibility to apply for family reunion. School education for first and second generation migrants in the native language of their parents was substantially enhanced (Kubat et al., 1979). By recognising the right of migrants to keep their ethno-cultural identity, these social policies had a double aim: on the one hand, they strove to improve the interaction between migrants' families and the hosting community; on the other hand, they intended to foster migrants' ties with their home countries to facilitate their eventual return to their countries of origin.

In the second half of the 1970 s both these integration policies and the support for return migration were failing to help south Mediterranean sending countries and their labour forces cope with the consequences of the first oil shock, leading to a steady increase of emigration from non-EEC sending countries to EEC countries. This was especially the case for migrants from Turkey in FR Germany and from the Maghreb in France. ${ }^{\text {iv }}$. The grey economy of former 
emigration countries was also attracting a large number of the new waves of immigration. Italy and eventually Greece and Spain became countries of immigration in the 1980s, as they obtained EEC membership (Greece in 1981 and Spain - together with Portugal -in 1986) (Fielding, 1993, pp. 50, 51; King, 1993, 2001). In fact, in the early 1980s, many non-EEC migrants reached the north Mediterranean borders of the EEC with plans to find a way to migrate further to north-western Europe, where their relatives and co-nationals had previously found employment and settled.

The introduction of more restrictive entry policies in the 1980s aimed to curb this unwanted and uncontrolled inflow of people from countries in the south towards countries in the north of the Mediterranean. Yet, these restrictions were not only targeted at the new wave of immigration but were endorsed along with measures to support return migration of non-EEC nationals whose presence was increasing greatly in the 1970s and 1980s. This was especially the case for migrants from the Maghreb in France and migrants from Turkey and Yugoslavia in West Germany. These restrictions imposed on the movement of citizens of non-EEC countries went hand in hand with a stronger emphasis on the alleged cultural distance which existed between 'European' and 'non-European' countries. A case in point was the question of Turkish migrants in Germany and Turkish EEC accession. Turkey was one of the first nonfounding members to join the Council of Europe in 1949. Turkey was also a founding member of the OECD and OSCE, which made Turkey a natural candidate for EEC membership. Indeed, Turkey obtained the status of an EEC associated member in 1963 and it was envisaged that Turkish migrants would be granted the same status as EEC workers by the end of 1986 at the latest (Comte, 2015, p. 114). However, negotiations over Turkey's membership of the EEC became complex and stalled (Arikan, 2003). In 1981, the EEC accepted West Germany's request to postpone concluding an agreement with Turkey. 
Highlighting the difficulties faced by the German labour market at that time, the German delegation at the EEC, supported by the Greek delegation, blocked the extension of the privileged status to Turkish migrants and asked for specific limitations on the right of movement of their family members in and to the EEC (Comte, 2015, p. 114, 115). The targeting of Turkish migrants had to do not just with economic concerns, and political developments, related to the military coup in Turkey. They were motivated by cultural considerations too. The German government considered reducing the number of Turkish guest workers in Germany by half, offering them up to 10,500 German Marks of the social fund in economic aid. This was because these nationals were allegedly, on account of their cultural differences, likely to be in tension with German and European values (Chin, 2007, pp. 150154). ${ }^{\mathrm{v}}$

While the mobility of Turkish migrants was restricted, the impact of the 'commuters of tomorrow' (OECD, 1988, as quoted in Mesić \& Heršak, 1989, p. 13) was welcomed in political debates about the future of European economic migration. This was a reference to former labour migrants, who, through their ties both in their countries of residence and origin, favoured the transnational exchange of ideas, goods and development (Mesić \& Heršak, 1989, p. 13). This policy contrasted in important ways with the policies of the 1970s, despite some continuities. In the 1970s, support for the transnationalism of migrants and for return migration were not mutually exclusive, since both were meant to facilitate economic cooperation and further European integration. In the 1980s, by contrast, transnationalism and return migration developed into two distinct migration policies which, when applied case by case, created rather different relations between EEC's sending and hosting countries. The signing of the first Schengen Agreement in 1985 gradually granted to EEC member state nationals the right to freely move between sending and hosting country, thus supporting their 
transnationalism. The transnationalism of migrant workers from countries that were not yet close to being part of the European community became less desirable, so that their plans to return to their countries of origin and remain there were strongly supported. This included citizens of countries in the south Mediterranean, and Turkey in particular.

Although sources suggest that, unlike Turkish migrants, Yugoslav migrant workers were not considered 'culturally' problematic by German state authorities and employers, who emphasised that Yugoslavs were valuable workers who easily adapted to the Western European environment (Molnar, 2014, p. 140, 2016, pp. 198-200; Ivanović, 2012, p. 308), the Yugoslav leadership was nevertheless concerned about its citizens residing in Western Europe. Like Turkey, Yugoslavia was a 'third country' (not a member of the EEC or its affiliated regions). Over a million of its citizens resided in Western Europe, a large proportion of whom, like migrants from Turkey, were employed in West Germany. ${ }^{\mathrm{vi}}$ Moreover, the temporary employment of Yugoslav citizens abroad, legalised in Yugoslavia in 1963, continued even after the abrogation of recruitment agreements in 1974. Like sending countries on the southern bank of the Mediterranean Sea, Yugoslavia was severely affected by the first and second oil shocks, and this was one reason why the outflow of workers continued during the 1970s along with the beginning of a process of settlement overseas of workers who had left in the 1960s. These developments in Yugoslav migration patterns led the Yugoslav government to participate in international cooperation on return migration ${ }^{\mathrm{vii}}$ and, at the same time, to enhance the financing of curricula, cultural and entertainment events for its citizens residing abroad. ${ }^{\text {viii }}$

Unlike Turkey and other Mediterranean sending countries, however, Yugoslavia, as a country of the Balkan area ruled by a communist leadership, was not in the process of negotiating 
EEC membership. Yugoslavia was not a country of the Eastern Bloc either and it had an independent foreign policy. In fact, in negotiations with the EEC, Yugoslavia defined itself, and was defined by EEC institutional bodies, as a "Mediterranean, European and Non-aligned country". ${ }^{\text {x }}$ Because of its peculiar geo-political position, Yugoslavia enjoyed intense economic relations with the EEC thanks to its independent position in international relations, and in particular its leading role in the Non-Aligned Movement (NAM). Yugoslavia was a moderate in NAM and restrained radical pro-Soviet and Chinese influences in the movement, which was greatly appreciated in the West (Jakovina, 2011, Chapter 4; Rubinstein, 1970, pp. 71-72, 328; Zaccaria, 2016, pp. 13, 36, 48, 69). Yugoslavia's involvement in the NAM was also a factor of domestic stability, since it contained conflicts between pro-Soviet and proWestern factions within the Yugoslav leadership. In the early 1980s, however, the death of Tito, together with the economic crisis and changes in Cold War power relations, challenged Yugoslav relations with Western Europe and the ability of its federal system to face a stalemate in domestic cooperation. Since, as this section has shown, the regulation of international migration was a key aspect of the relation between the EEC and its peripheries; and since migration was an important factor for Yugoslavia domestically; changes to the migration regime prompted by the two oil crises played an important part in the Yugoslav crisis of the 1980s.

The impact of the second oil shock on the Yugoslav crisis. Regional perspectives on economic development and emigration towards western Europe

The second oil shock dramatically exposed the dependency of the Yugoslav economy on the world market economy and exacerbated political tensions amongst the Yugoslav republics over development strategies (Zimmerman, 1987, p. 138; Allcock, 2000, pp. 424-426; Jović, 
2009, pp. 155,156). That a dramatic economic turn was coming became evident in 1979 when Yugoslavia's foreign debt reached a record high. Foreign currency reserves dried up as countries refused Yugoslavia's requests for loans due to the escalating crisis in Poland (Woodward, 1995b, pp. 252-254; Martin \& D’Andrea Tyson, 1985). A loan of 340 million dollars that was finally granted by the International Monetary Fund (IMF) came with the request for a stronger export orientation and the implementation of economic reforms. The federal parliament passed these reforms in 1983 as the Programme for Economic Stabilization (Schierup, 1990, pp. 292, 293; Allcock, 2000, pp. 95, 96). However, the federal government's attempt to exercise greater control over the trade revenue and expenditure of the republics $-\mathrm{a}$ condition demanded by the IMF as a prerequisite for securing any additional loans - did not succeed. In 1985, Slovenia's refusal to pay its federal contribution was followed by the abrogation of the Programme for Economic Stabilisation. ${ }^{\mathrm{x}}$ One of the main reasons for disagreement within the Yugoslav leadership was that the republics advocated divergent solutions to overcome the crisis; the less-developed republics (Macedonia, Montenegro, and Bosnia-Herzegovina), and Serbia, advocated subsidies to protect the domestic market, while the most developed republics, Slovenia and Croatia, pressed for a greater export orientation and increased integration in the world market economy (Woodward, 1995a, pp. 63-74; Calic, 2011, p. 75).

The relations that each of the Yugoslav republics enjoyed with Western Europe accounted for many of the differences in their responses to the crisis of the 1980s, as well as the differences in their economic development. Since the 1950s, Western Europe had become Yugoslavia's main economic partner (Obadić, 2014; Zaccaria, 2016). This openness to the Western European market came with the introduction of economic reforms that endorsed the decentralisation of resources and decision-making at the expense of the federal apparatus - an 
apparatus that was the main instrument for fostering the equal development of the different Yugoslav regions (Horvat, 1976, pp. 60-75). The attainment of equal development, which had been a priority in the post-war period, was made a secondary goal in the mid-1960s when the introduction of market mechanisms in economic development plans privileged exports over the domestic economy and promoted the transition from extensive to intensive system of production (Pleština, 1992). Labour emigration towards western Europe had been an important aspect of this strategy. By alleviating unemployment and providing remittances, employment abroad was meant to help restore the rapid development which had begun to falter in 1963. The outcome proved rather different, however, as employment abroad and its regulation in fact served to increase the regional disparities it was supposed to alleviate. More precisely, because those regions that were geographically closer and better connected to Western Europe were also the most developed, economic disparities between the northwestern and south-eastern regions of Yugoslavia deepened.

Yugoslav regional disparities placed the Yugoslav federation and each of its republics in different position vis-à-vis the poorest countries in western Europe. For example, in 1987, per capita income in Macedonia was 400 dollars while in Slovenia it was 4,500 dollars. ${ }^{x i}$ In 1983 , the GDP per capita in Yugoslavia was 2,570 dollars, in Portugal 2,190, in Greece 3,970, in Ireland 4,810. Macedonia was well behind Portugal, the Yugoslav federation between Portugal and Greece, and Slovenia above Greece and close to Ireland. ${ }^{\text {iii }}$ This difference in Yugoslav economic development by republic was the reason why Yugoslavia was described in EEC parliamentary discussions about the future of EEC-Yugoslav relations as "half a developed [referring to Slovenia and Croatia] and half a developing country [all the other republics]" xiii This duality of Yugoslav development helps explain why in the same discussions it was stressed that cooperation agreements with the EEC should grant better 
conditions of trade and fairer distribution of products within the EEC market to the welldeveloped industries of Croatia and Slovenia in particular. ${ }^{\text {xiv }}$

This increase in regional disparities, and the links between regional disparities and the different relations which individual Yugoslav republics established with the EEC, were two important reasons why Yugoslavia experienced many difficulties in meeting its development plans. Employment abroad played a role in these difficulties because it tended to reproduce pre-existing patterns of socio-economic underdevelopment and their inter-independence on a larger and transregional or transnational scale. By doing so, employment abroad could also help reconfiguring relations between Yugoslav and EEC regions and countries. This is proven by the fact that several documents of EEC institutions made clear that the Yugoslav workers residing in EEC member states was a relevant factor which would have a prominent importance in the future of relations between the EEC and Yugoslavia. ${ }^{\mathrm{xv}}$ Emblematically, Italy and FR Germany, the main Yugoslav trade partners within the EEC - these two countries absorbed 70 percent of total Yugoslav exports to the EEC - contained the largest numbers of Slovenes (because of the presence of the Slovene minority in Italy) and Croats (because the majority of Gastarbeiter were in FR Germany and, of those, most were of Croatian nationality).

Regional disparities and Yugoslav workers' distribution in Western European countries were also related to the pace and stage at which Yugoslav regions became involved in international migration. In socialist Yugoslavia, post-war external economic migration towards Western Europe began in the second half of the 1950s, when it was an illegal phenomenon mostly confined to the north-western Yugoslav border regions (Brunnbauer, 2009, p. 45). In the early 1960s, workers' emigration continued to increase and expand in Slovenia and Croatia, despite 
being prohibited until 1963, when it was legalised as temporary employment abroad (Haberl, 1978, pp. 62-69). In the following years, as Yugoslavia signed numerous agreements with the principal recruiting countries in Western Europe and Australia, labour emigration rapidly became a widespread practice. According to the population census held in 1971, of a total Yugoslav population of 20,505,000, the number of Yugoslav workers employed abroad was estimated $^{\mathrm{xvi}}$ as between 700,000 and 900,000, accompanied by about 300,000 family members $^{\text {xvii }}$ (Baučić, 1973, p. 204). The different regions of Yugoslavia were unevenly affected by labour emigration: of the 671,908 Yugoslavs registered as 'temporarily employed abroad' in 1971, the majority came from the northern republics of Croatia (33.4 percent) and from Bosnia-Herzegovina (20.4 percent). Slovenia, which had been one of the two principal emigration areas in the early 1960s (along with Croatia), experienced a decrease in its emigration rate during the 1960 s, with the rate falling to 4.5 percent of the population by 1971 (Zimmerman, 1987, pp. 74-105).

While labour emigration towards Western Europe declined in Croatia in the 1970s, it increased in Bosnia-Herzegovina and in the central and south-eastern areas of the federation which had only been slightly affected by this phenomenon in the previous decade. (Brunnbauer, 2009, p. 28; Zimmerman, 1987, pp. 100-102. This shift was particularly visible in Serbia (Tanić, 1974, pp. 31, 85, 89). As shown by the comparison of data provided by the population censuses held in 1971 and 1981 (Table 1), the number of Yugoslav workers employed abroad who were from Croatia decreased substantially, while in Serbia they increased in number by 50,000 compared to 1971, and those from Montenegro and Kosovo by one-quarter and one-fifth respectively.

[Table 1 near here] 
The relative shift in labour emigration from the north-western to the central and south-eastern Yugoslav regions was driven by the rise in unemployment generated by the economic reforms implemented in the second half of the 1960s. Attempting to shift from an extensive to an intensive industrialisation, these reforms introduced new taxation and price systems as well as other measures with the goal of rationalising the governance of the public sector. While this offered some benefits to the most advanced industrial sectors, for large enterprises whose economic function was more to absorb unemployment than generate profit, the reforms led to drastic cuts in work places (Woodward, 1995b, pp. 191-210; Schierup, 1990, pp. 78, 79). These types of enterprises were particularly prevalent in the central and south-eastern Yugoslav republics and in regions with a predominantly rural population. In these areas, there was widespread recruitment of part of the rural population who, in addition to their work in agriculture, commuted to the nearest industrial centres to be employed on a temporary basis as the lowest skill level of factory workers (Horvat, 1976, pp. 79-87; Rusinow, 1977, pp. 203205; Vuksanović \& Tomić, 2011, pp. 178-197). Thus, as emigration moved south-east, and included peasants, it also acquired a more rural character than it had had in the 1960s. ${ }^{\text {xvii }}$ The number of peasant migrants was particularly high in Bosnia-Herzegovina, Kosovo, Macedonia, Montenegro and Serbia proper, while in Slovenia, Croatia and Vojvodina peasants only accounted for between one third and two fifths of the workers employed abroad (Tanić, 1974, p. 20).

The ruralisation of labour emigration was not only related to the impact of Yugoslav economic reforms on regional socio-economic structures but was also part of macro-economic changes which affected the broader European phenomenon. These changes included the process of deindustrialisation and technological innovation pushed through in the 1970s in 
Western Europe (Schierup, 1990, pp. 1, 2) and the impact of industrialisation on rural areas in the Mediterranean regions (Tanić, 1974, pp. 19-21). Deindustrialisation and restrictive entry policies in Western Europe favoured the flourishing of seasonal and informal recruitment of low-skilled migrants, mainly in the service sector, tourism, and construction. Destination countries also changed. This shift was visible even in Yugoslav data, despite the increase in irregular recruitment. In the 1960s, the large majority of Yugoslavs had left for FR Germany or France to work in the car industry. In the 1970s, though, it was the seasonal sectors of Austria and Switzerland which absorbed the majority of Yugoslav migrants. ${ }^{\text {xix }}$

This informal and unqualified migration was the object of specific concern to the federal government in the early 1980s, when Yugoslavia was severely affected by economic crisis. In particular, in late 1982, shortly before the adoption of the stability pact with the IMF, the federal government abrogated the economic privileges of returnees (such as the customs discounts and tax-free imports envisaged by reintegration policies), and implemented economic measures to discourage Yugoslavs from leaving the country and transferring money abroad. The Yugoslav Federal Executive Committee introduced an obligation for Yugoslavs leaving the country to leave a 5,000-dinar deposit, envisaging an additional 2,000 dinars for any additional travel. ${ }^{\mathrm{xx}}$ The interest rate on investments in Yugoslav enterprises was cut, while all customs concessions were withdrawn, with the exception of that for definitely returning workers (Zimmerman, 1987, pp. 114, 127).

This illiberal approach towards both emigration and return migration was motivated by the difficulties faced by the Yugoslav government in trying to intercept migrants' remittances, which remained outside of institutional control at a time when the debt crisis was increasing the need for foreign currency (Woodward, 1995b, p. 254). It also related to the loss of skills and expertise which characterised the Yugoslav economic migration to Western Europe since 
the 1970s. In fact, as migration policies became more restrictive and conditions of work worsened over time, those migrants who had left earlier (usually from the most developed republics) to be employed in the industry of western European countries had more chances of gaining skills and of having a positive impact on local development than migrants who left rural areas in less developed republics in the 1970s and 1980s to find employment as unskilled seasonal workers abroad. A look at return migration offers clear examples of this shift.

Although there are no comprehensive and accurate data on Yugoslav workers who returned to Yugoslavia, sources suggest that return migration increased in the aftermath of the two oil shocks - namely in the period 1974-1976 and then again in the early 1980s. These two peaks of return migration differed in several respects. In the earlier period, return migration mostly affected Slovenia and Croatia, whose workers had left even before the legalisation of employment abroad. These migrant workers were often recruited in expanding industrial sectors, mostly in France and West Germany, which offered much better salaries than those obtained in Yugoslavia as well as opportunities for gaining skills. These features of international labour migration were hailed positively in the domestic and international debate on return migration and were reasons for policies addressing returnees as a valuable and important force for the economic development of the country (Schierup, 1990, pp. 12-14). ${ }^{\mathrm{xxi}}$ In fact, although international cooperation on return migration eventually failed, it initially generated great enthusiasm and in some cases did succeed, at least at first. This was the case of the textile factory Pionirka in the poor Dalmatian hinterland (Winterhagen, 2006), and of the factory making hydraulic cylinders Hypos Muta in the Slovenian border area with Austria (Vedriš, 1978, pp. 64-68). ${ }^{\text {xii }}$

In the early 1980s, it was mostly the peasants from the central and south-eastern rural areas, above all Macedonia, Serbia proper and the autonomous province of Kosovo, who made their 
way back home. Unlike their predecessors, their training abroad had been very poor because they were recruited on a short-term and often informal basis for hard physical jobs which required no or only minimal qualifications. Moreover, they returned at a time when the Yugoslav federal government and the governments of hosting countries had lost interest in their return as a vehicle to promote economic cooperation and development. Back in their community of origin and left to their own devices, they mostly relied on machinery imported from abroad to cultivate their own land and used their savings to build or expand their family house (Nejašmić, 1981; Vedriš, 1979, pp. 74, 75; Tanić, 1974, pp. 78-84).

The meagre profits they gained from working in the agricultural sector pushed these migrants to search for additional forms of income (i.e. employment in the public sector), which the local market could not satisfy. Again, migrants left their local communities at a time when opportunities for employment were becoming less accessible and less secure in their country and in Western Europe. Closer destinations in developed areas of the federation became more attractive. This was the case of Slovenia, which, being the most developed Yugoslav republic, received an increasing number of workers from other republics. For this reason, although the Slovenian economy was better placed than any other within the federation, the oil shock had a particular effect on Slovenia. The consequences of the changes occurring in the labour market of Western Europe were not limited to the increase in domestic migration. The process of European enlargement in the north Mediterranean area also strengthened ties between communities of Slovenes ${ }^{\text {xxiii }}$ living in Slovenia and nearby countries. The interaction of labour immigration to Slovenia and transnational ties among communities of Slovenes contributed to the articulation of the Slovenian path to independence by making the increasing economic disparities between the Yugoslav republics more socially and politically relevant. 
Labour immigration and transborder regional cooperation in the awakening of the Slovenian European identity. A path towards independence

Although economic migration towards Western Europe assumed greater importance for socialist Yugoslavia following its legalisation in 1963, domestic migration continued to remain important. Yugoslav domestic migration was mostly regional (often occurring within the same municipal area), while intra-republic migration was less common (Rančić, 1990). The patterns of regional and intra-republic migration were affected by changes occurring in emigration patterns towards Western Europe. In particular, domestic migration intensified when Yugoslav emigration was made more difficult or return migration occurred, as happened in the aftermath of the first and second oil crises. Moreover, in both crises, south-eastern regions, and rural areas in particular, were more dramatically affected by the economic downturn, with an increase in domestic migration from south to north and from rural to urban areas. As mentioned above, Slovenia and its urban centres were among the leading destinations of this migration.

Immigration to Slovenia first became an important phenomenon in the mid-1960s at a time when emigration from Slovenia to Western Europe was a widespread phenomenon (Meznarić, 1986, pp. 60-64). Slovenian emigration to neighbouring Western countries was one of the reasons for the increasing vacancies in Slovenian industrial areas, most of which were filled by workers from other republics (Meznarić, 1978, pp. 305-306). Slovenian migrant workers could easily find employment abroad that was economically more advantageous than a job in Slovenia. For workers from other republics, meanwhile, the Slovenian labour market offered greater possibilities and economic gains than the jobs they could find in their own republics. Slovenian enterprises were unsatisfied with immigrants from the south of Yugoslavia because 
they were allegedly largely unskilled at a time when the Slovenian labour market was in need of skilled workers. ${ }^{\text {xxiv }}$ Despite this, immigration from other republics was accepted as a correction to the inefficiencies of the Yugoslav domestic market, which also affected the Slovenian domestic labour market. ${ }^{\mathrm{xxv}}$ In particular, Slovenian enterprises increasingly looked abroad for the recruitment of skilled workers, ${ }^{\text {xxvi }}$ while the immigrants reaching Slovenia from the southern regions of the federation were employed in physically hard and intensive jobs which were less attractive to Slovenes. ${ }^{\text {xxvii }}$

Already in the second half of the 1970s, however, Slovenian enterprises were beginning to take a more cautious approach towards the recruitment of workers from other republics. In particular, sources show that the municipality of Ljubljana began to complain about the social disorders caused by migrants from other republics encamped at the train station, and asked other republics to take action to limit emigration of workers who left without having a job contract in Slovenia. ${ }^{\text {xxviii }}$ Despite this, immigration to Slovenia continued to increase in the 1970s; in the early 1980s some 20-25 percent of the total labour force employed in Slovenia's secondary sector were still citizens of other Yugoslav republics (Woodward, 1995b, p. 365; Heršak, 1986, p. 248 quoted in Schierup, 1990, p. 276). This was because, although all Yugoslav republics were affected by the rise in oil prices and its consequences, Slovenia was the only republic with a very low unemployment rate that was declining while it was increasing everywhere else in Yugoslavia (Woodward, 1995b, p. 206-209; Korać, 1981, pp. 1335, 1336). For this reason Slovenia was not only a destination for workers who migrated in the domestic Yugoslav labour market but also for those employed overseas who had been dismissed or were recruited for seasonal jobs in nearby Italy, Austria and Switzerland. 
Nonetheless, immigration from other Yugoslav republics to Slovenia fell by about 10 percent in the period 1980-1984 (Malačič, 1989, p. 329; Meznarić, 1986, p. 74). One of the reasons seemed that, in the early 1980s, the likelihood of intra-republic migration was undermined by the rise of ethnic tension in Yugoslav labour relations. This tension emerges clearly in several sociological studies. For example, cases of discrimination against Kosovo Albanian workers were reported in Serbia (Magnusson 1987, p. 276-277), while in Croatia a sociological survey revealed that to the question what change was less acceptable among change of job, profession, city or republic, this last was defined as the worst possible one (ibid. p. 277). Other sociological studies revealed that ethnic tension had grown over time and varied in different Yugoslav regions. They sugggested that lowest ethnic diversity of the population was correlated to highest ethnic distance (Allcock, 2000, pp. 192-198).

This latter was the case of Slovenia. Indeed, other sources suggest that Slovenia was more affected by ethnic tensions than other Yugoslav republics. Susan Woodward reports that conversations with officials and social scientists in Ljubljana revealed that Slovenian authorities discussed the possibility of taking action and sending back Bosnian and ethnic Albanian workers. ${ }^{\text {xix }}$ The Slovenian planning bureau would have justified the closing of the borders to immigrants from the other Yugoslav republics on account of the threat that immigration posed to Slovenia's national and cultural distinctiveness (Woodward, 1995a, pp. 63, 64; Woodward, 1995b, p. 365). No ban on immigration was ever issued, however, suggesting that further research in the archives may be necessary to corroborate Woodward's argument. Nonetheless, many contemporary sociological studies reported frequent episodes of social discrimination against national groups from other Yugoslav republics in Slovenia, which, along with the decrease in Yugoslav immigration to Slovenia, and the rise of ethnic tension in all Yugoslav republics, makes Woodward's study entirely plausible (Davidović, 1986, pp. 343, 344; Jović, 2009, p. 146; Meznarić, 1986; Schierup, 1990, p. 276). 
Several authors also suggest that the animosity generated by the number of immigrants from Yugoslavia's southern republics in the Slovenian labour market bore many similarities to xenophobic attitudes displayed towards migrant workers in Western Europe (Davidović 1986; Schierup 1990, p. 276). These similarities between the attitudes of the Slovenian authorities towards migrant workers and the attitudes of recruiting countries in Western Europe were symptoms of broader changes which, while they involved both Western Europe and Yugoslavia, led to rather different outcomes. While change was coupled with policies in Western Europe that strengthened the project of European integration, in Yugoslavia the opposite occurred.

Despite these different trajectories, developments in Western Europe still affected developments in Yugoslavia. The ferment amongst cultural and intellectual circles about the Slovenian nation belonging to Europe provides a clear example of this relation. Discontent in the early 1980s with the difficulties of coexistence in a federation that was increasingly perceived as an unnatural home for Slovenia was not confined to political authorities and socio-economic political bodies lamenting conditions in the labour market. Intellectual circles and politically engaged Slovenian youth also gradually became more critical of the central government and its representative bodies (Patterson, 2010). Although the anti-centralist stance that characterised the cultural ferment in Slovenia in these years was certainly a result of the crisis of the Yugoslav system, this stance did not develop in isolation. It was from abroad that Slovenia found support and evidence that what distinguished Slovenia from the other republics was that, while the latter were characterised by their backward Balkan traditions, Slovenia belonged to Europe, with which it shared cultural values and its Mitteleuropean roots (Patterson, 2003).

The appropriation of the concept of Mitteleuropa as a geographic and cultural entity in the Slovenian pro-independence debate of the second half of the 1980s was not a Slovenian 
'reinvention', however, but a phenomenon involving the broader central European region where intellectuals and writers re-invoked their sense of being part of Mitteleuropa. ${ }^{\text {xx }}$ Indeed, the revision of European cultural boundaries was not unrelated to European détente and the path it took in the first half of the 1980s. More precisely, the inclusion of Greece, Spain and Portugal in the EEC and the closure of the EEC borders towards immigration from the Muslim and less developed southern Mediterranean bank was accompanied by the relaunching of transregional cooperation at its more developed and Catholic central-eastern borders intended to overcome ideological barriers between western and eastern Europe. The Alps-Adria community was an emblematic example of these forms of collaboration. ${ }^{\text {xxxi }}$

The Alps-Adriatic working community was a project of transregional cooperation that initially included Slovenia and Croatia, three Austrian Länder (Upper Austria, Carinthia, Styria) and two Italian regions (Veneto and Friuli-Venezia Giulia). The aim of the community was to foster economic and cultural cooperation across the borders of the countries involved, creating a free industrial zone and drawing on the multicultural and multi-ethnic composition of this area as its strength. ${ }^{\text {xxii }}$ The idea of the Alps-Adriatic macro-region had been considered as early as in the 1960s, mostly to help overcome tensions between Italian, Austrian and Yugoslav governments over contested areas. These proved difficult to surmount at the time, but the idea of regional cooperation received a boost at the Helsinki summit and an agreement was signed in 1978 (Bucarelli, 2008, pp. 76-81; Jurić Pahor, 2012). It was only in the 1980s that the community assumed an active role in transregional cooperation, thanks also to its further inclusion of the Italian regions of Lombardia and Trentino-Alto Adige, the two Austrian Länder of Salzburg and Burgerland, the Hungarian regions of Györ-Sopron, Somogy, Vas and Zala, and the German Land of Bayern. As many scholars have noted, with the exception of Bayern, the Alps-Adriatic group gradually resembled a smaller version of the Austro-Hungarian Empire and the idea of central Europe as a cultural and geopolitical unity 
that the Empire embodied (Bucarelli, 2008, p. 78; Mesić \& Heršak, 1989, pp. 18, 19; Devetak, 1988; Gow \& Carmichael, 2010, pp. 195, 196).

The enlargement of the Alps-Adriatic community in the former Habsburg territories and the increasing emotional commitment the Habsburg legacy enjoyed among its members in the second half of the 1980s was not the result only of European détente and the direction taken by European integration. It was also influenced by the ways changes in the global Cold War challenged the bipolar equilibrium in Europe. In the first half of the 1980s the decline of the geostrategic importance of Africa in the US-Soviet competition over the Third World were factors that directly and indirectly shaped relations between western and eastern Europe (Westad, 2005, pp.378-380; Grilli, 1993, Chapter Eight). Certainly they were factors which challenged the relations between Yugoslavia and Western Europe, as these relations were strongly connected to the Yugoslav role in the global Cold War and in particular its position in the NAM (Jakovina, 2011, pp. 251, 303, 304). In the 1980s, the NAM was afflicted by its inability to overcome internal divisions, which dramatically affected its bargaining power with the Blocs (Prashad, 2007, pp. 276-281). For Yugoslavia, which was facing both its own domestic crisis and the crisis in the NAM without the leadership of Tito, cooperation with Western Europe assumed a different character. This was probably one of the reasons why, as Klabjan shows, the Yugoslav Federal Assembly welcomed the Alps-Adriatic agreement, even though it involved only the republics of Croatia and Slovenia (Klabjan, 2013). Resembling a form of cooperation that could help overcome east-west divisions, the Alps-Adriatic agreement converged with the vision of Yugoslav internationalism based on diplomatic relations independent of the superpower blocs and close economic relations with Western Europe.

Nevertheless, it was among the communities of Slovenes inhabiting the Italian and Austrian parts of the Alps-Adria community that the more radical positions on Slovenia's right to 
independence were formulated on the basis of ethnic claims, even before the debate on Mitteleuropa gained ground. In 1985, a Vienna-based Slovenian newspaper published an article by the economist Jožko Šavli in which the author expounded the so-called Venetological theory which, as Zlatko Skrbiš (2007, p. 138) explains "sought to rewrite the history of the Slovenian nation by arguing that Slovenians are indigenous to the European continent and thus unrelated to any surrounding ethnic groups". Maintaining that "Slovenians are descendants of the proto-Slavic Venets living around 1200 BC" Slovenian Venetological theory further asserted that 'the Slovenians are an autochthonous European population and this quintessential Europeanness makes them the first builders of the European community" (ibid, p. 143).

As Skrbiš explains, the Venetological theory was not afforded credence in academic circles in Slovenia or abroad. Moreover, the Venetological theory and its supporters were only a minor and not the most influential part of the Slovenian diaspora. Support for its genealogical claims remained confined to conservative diaspora circles. Its radicalism and sectarianism notwithstanding, the Venetological theory was the product of a cultural background (Catholicism and anti-Communism) that provided the foundation for alliances between Slovenian and European Democratic Christian parties that backed and lobbied for the recognition of Slovenian independence and eventual EEC membership (Radeljić, 2012, pp. 111-119).

\section{Conclusion}

Several studies undertaken in the last two decades have shown how long-distance diaspora communities became involved in the Yugoslav collapse, providing media and financial 
support to their co-ethnic leaderships during the wars and eventually in the rebuilding of independent national states. However, the extensive Yugoslav economic migration and the presence of Yugoslav ethnic minorities in Western Europe, as well as the interaction of this migration with the Yugoslav crisis of the early 1980s, remain under-researched. This article has set out to offer a modest contribution on this neglected topic. It has done so by illustrating how the two oil shocks and the process of European integration affected Yugoslav migration patterns differently, and has explored how these differences were a cause of increasing political division in the crisis of the 1980s because they reflected the different relations which Yugoslav republics enjoyed with Western Europe as well as regional economic disparities. To prove its case this article has focused on the case of Slovenia, whose geographic proximity and historical legacy meant it was affected in a peculiar way by changes in migration policies in Western Europe.

More precisely, this article has shown that, in the second half of the 1970s, Slovenia, already a destination of domestic intra-republic migration on account of its being the most developed Yugoslav republic, also became a destination for those Yugoslav migrant workers whose international mobility was now restricted by the limitations imposed on the international labour mobility of non-EEC citizens in Western Europe in the aftermath of the first and eventually second oil shock. The article has explained how reactions by the Slovenian authorities and strata of the Slovenian society to the increase in labour immigration first, and the ethnic composition of this immigration eventually, bore similarities to the displaying of xenophobic attitudes in western European recruiting countries toward migrants from the south Mediterranean area. This article has contended that these similarities reflect the fact that Slovenian resentment of domestic immigration was motivated not only by the domestic crisis but also by new developments in the broader European region. 
Furthermore, the article has illustrated how within the communities of Slovenian minorities living in nearby Italy and Austria, a new theory about the European ethnic origin of Slovenes and their belonging to the community of European nations was being elaborated already in the first half of the 1980s. This was before the European character of the Slovenian nation became widely promoted in the Slovenian pro-independence public discourse in the second half of the 1980s. The earlier development among the Slovenian European diaspora of some of the core ideas which eventually led Slovenia towards independence was driven by the fact that the Alps-Adriatic region they inhabited was part of a project of transregional cooperation aimed at bridging ideological divisions in Europe through the links established by ethnic minorities across state borders. Since the Alp-Adria cooperation, as well as the new migration policies of western European countries, were both symptoms of changes in the Cold War equilibrium that had granted Yugoslavia domestic stability and privileged relations with Western Europe, analysis of these phenomena placed the crisis of Yugoslav federalism and Slovenia's path to independence in a broader European and Cold War story.

Accordingly, while the role of long-term migration and long-distance diasporas has been noted in the disintegration of Yugoslavia and the nation-building processes that followed, this article has shown that short-term migration and short-distance diaspora communities played a key role in the particular pace and nature of the Yugoslav crisis, which was interrelated to historical legacy, changes in the Cold War equilibrium and the new phase in the process of European integration in Western Europe, and the impact which all of these factors had on Yugoslav domestic relations.

\section{Acknowledgments}


I would like to thank the anonymous reviewers, Marco Abram, Catherine Baker, Eloisa Betti, Maud Bracke, Zoi Pittaki, Francesca Rolandi, Angela Romano, Sabine Rutar, and Vladimir Unkovski-Korica for their insightful comments on earlier drafts of this article.

' Indeed, there are also scholars who attribute a different role to Western powers during the crisis of the 1980s. For example, Woodward (1995a, 1995b) and Samary (1995) stressed the role of Western powers in bringing the Yugoslav federation into a stalemate, mainly by imposing economic reforms which increased disparities and division between the most developed and less developed Yugoslav republics.

ii Western Europe is here used as a broad and elastic geographic and geo-political definition, since the article analyses Yugoslav diplomatic relations with specific western European countries, the European Economic Community (EEC), and EEC member states.

iii Before 1918, Slovenia, as well as Croatia and Vojvodina, belonged to the AustroHungarian Empire from which they inherited institutional and informal channels of economic migration towards Central and Western Europe. See, for example, Schierup (1990, pp. 28-30).

${ }^{\text {iv }}$ For data on migrants from Turkey in West Germany, see Abadan-Unat (1993). For migrants from the Maghreb in France, see Comte (2014) and De Tapia (2008, p. 49).

${ }^{v}$ Recent declassified records of a private meeting in October 1982 between the German Chancellor Helmut Kohl and the British Prime Minister Margaret Thatcher, confirms that the German Chancellor considered this plan. Record of a conversation between the prime minister and the chancellor of the Federal Republic of Germany at 1930 hours on 28 October in Bonn, 28 October 1982, Collection PREM (Prime Minister's Office Files), fasc. 19, doc. 1036, The National Archives of the UK, London, p. 1-3.

${ }^{\text {vi }}$ In 1984 there were about 612,000 Yugoslavs residing in West Germany. For an overview of the problems they faced in the German labour market of the early 1980s, see (Pusić, 1985).

vii Savezni Komitet za Rad i Zapošljavanje (Federal Committee for Employment), Belgrade 22.07.1974, Mišljenje o predlogu SR Nemačke da se razmotri mogućnost zaključivanje posebnog sporazuma o stručnom obravozanju jugoslovenskih radnika zaposlenih u SR Nemačkoj koji nameravaju da se vrate u Jugoslaviju [Opinion on the proposal of the Federal Republic of Germany to consider the possibility of concluding a special agreement on the professional detachment of Yugoslav workers employed in the Federal Republic of Germany who intend to return to Yugoslavia], box 577, folder 6c, Archives of Yugoslavia, Belgrade.

viii Centralni komitet saveza komunista Srbije (Central Committee of the League of Communists of Serbia), Belgrade 04.1976, Zaključci o informativo-propagandnoj delatnosti među našim radnicima na privremenom radu u inostranstvu [Conclusions on informativepropaganda activity among our workers on temporary work abroad], box 142-II, folder 705 . See also Baković (2012) and Ivanović (2012, pp. 143-220).

ix Radeljić (2017b, p. 38); The interim report by Mr De Clercq Brussels, 13 November 1978, State of Commercial and Economic Relations between the EEC and Yugoslavia, European Parliament, 407/78. In Radeljić, 2017a, p. 158; The debate on the report drawn up by Mr Radoux on behalf of the Committee on External Economic Relations Brussels, European 
Parliament, sitting of 22 May 1980, EEC-Yugoslavia Cooperation Agreement, (Doc. I165/80), in: Radeljić (2017a, p. 205); Statement by Budimir Lončar, the Minister for Foreign Affairs of Yugoslavia, Brussels 19 December 1988, Seventh Meeting of the EEC-Yugoslavia Cooperation Council at Ministerial Level, (in the European Commission, CEE-YU 1019/88) (Annex II/A). In Radeljić 2017a, p. 447.

x The Stability Pact was reintroduced in 1988 (Woodward 1995b, pp. 256, 363-365).

${ }^{x i}$ EEC-Yugoslavia Debates of European Parliament, 15 December 1987, No.2-358/89. In Radeljić, 2017a, p. 389.

xii European Commission (RELEX III/1987), Brussels, 27 March 1987, Relations with Yugoslavia, The EEC-Yugoslavia Cooperation Agreement, Annex to Annex IV Yugoslavia: Basic Data. In Radeljić, 2017a, p. 378.

xiii Oral question (O-68/77) with debate, by Mr Bettiza, Mr Cifarelli, Mr Damseaux, Mr De Clercq, Mr Geurtsen, Mr Zywietz and Mr Bangemann to the Commission of the European Communities Brussels, 14 November 1977, Economic Relations between the EEC and Yugoslavia in the Light of the Future Cooperation Agreement, European Parliament, 370/77. In Radeljić, 2017a, p. 113.

${ }^{\text {xiv }}$ Ibid, pp. 114-115.

${ }^{\mathrm{xv}}$ Ibid, p. 113; See also EEC-Yugoslavia Economic Relations Debates of the European Parliament, 19 January 1988, No.2-360/106. In Radeljić, 2017a, p. 418. In order to strengthening the relations between Yugoslavia and the Council of Europe in the field of migration, Yugoslavia was invited, in 1988, to attend the meetings of the European Committee on Migration as observer. Yugoslav Labour and Employment in the Community Summary record of the meeting of the Working Group of the Member States and Yugoslavia Brussels, 9 September 1988 [listed under 18 November 1988], Council, CEE-YU 1008, Annex II. In Radeljić, 2017a, p. 443.

${ }^{x v i}$ The registration of labour migrants, both leaving and returning, presented several problems which were related, among others, to informal recruitment and different classifications used by Yugoslav and foreign countries' institutions to count and classify data. The reliability of estimates decreased after the first oil shock when the abrogation of intra-state bilateral recruitment agreements brought about a proliferation of irregular channels and practices of recruitment.

xvii In the population census held in 1971, migrants' family members were counted together with families of diplomatic and other representative institutions. In the population census of held in 1981, however, migrants' family members were treated as a separated category.

xviii While in 1961 peasants made up only a quarter of the total number of migrants employed abroad, in 1976 they comprised over half of all Yugoslavs employed abroad (Veselinov, 1987, p. 115).

${ }^{x i x}$ For example, in 1978 registered Yugoslavs leaving for employment abroad recruited in Austria were 27.5 percent and in Switzerland 14.1 percent (and increasing) of the total recruited, while France and Germany accounted for the recruitment of only 6.8 and 4.8 percent of the total recruited respectively. (SOPEMI 1981, p. 11).

${ }^{x x}$ The obligation, which was very unpopular, was lifted soon after. 
xxi Savezni komitet za rad i zapošljavanje (Federal Committee for Employment), 02.1976, Belgrade, Program mera i akcija za postepeno vraćanje jugoslovenskih radnika sa rada iz inostranstva i njihovo radno angažovanje u zemlji [Program of measures and actions for the gradual return of Yugoslav workers from work abroad and their work engagement in the country], box 142-II, folder 748, Archives of Yugoslavia, Belgrade.

xxii Of these, however, only the latter was very successful and still exists today, while the former was never able to be competitive for export and eventually went bankrupt in the 1980s.

xxiii Communities of Slovenes is here used to define the ethnic communities of Slovenes which neither coincided with the territorial republic of Slovenia nor encompassed all Slovenian citizens but rather included the people who, irrespective of their citizenship or place of living, perceived themselves as Slovenes.

xxiv Silva Meznarić illustrates that the widespread assumption that immigrants from other Yugoslav republics were unskilled and poorly educated does not reflect the reality as data suggest that the numbers of unskilled but also of the highly educated immigrants from other republics was higher than the Slovenian average (Meznarić, 1986, pp. 73-74).

xxv Savezna Konferencija SSRNJ (Federal Conference of the Socialist Alliances of the working people of Yugoslavia), Ljubljana 10.1972, Stenografske beleške sa međurepubličkog savetovanja po pitanjima naših radnika zaposlenih u inostranstvu [Stenographic notes from inter-republican consultations on the issues of our employees working abroad], n. 2369/1, box 142-II, folder 749, p. 1/44.

${ }^{\text {xxvi }}$ Coverage of these campaigns was extensive in the press. See, for example: D. O. (1970, October 10). Po svoje stručnjake u SR Nemačku [In search of our own experts in Germany]. Borba; Krešimir Fijačko K. (1970 October 16). Bolja zarada, pa neće u svijet [Better wages, and they will not go overseas]. Vjesnik; Rupnik A. (1971, October 8). Izuci se - Plačamo ti! [Get out-We will pay you!] Delo.

xxvii Savezna Konferencija SSRNJ (Federal Conference of the Socialist Alliances of the working people of Yugoslavia), Ljubljana 10.1972, Stenografske beleške sa međurepubličkog savetovanja po pitanjima naših radnika zaposlenih u inostranstvu [Stenographic notes from inter-republican consultations on the issues of our employees working abroad], n. 2369/1, box 142-II, folder 749, p. 3. See also Korać, 1981, pp. 1329-1346; Meznarić, 1986, pp. 7677.

xxviii Samoupravna skupnost za zapošljavanje Ljubljana (Self-managing community for employment Ljubljana), 1.4.1976, Obaveštenje [Notice] n. 20/9-76, box 467, folder. 297.0231, n. 20/9-76, Archives of Yugoslavia, Belgrade.

${ }^{x x i x}$ In the second half of the 1970s, immigration from Bosnia-Herzegovina increased exponentially (46 percent of the total). (Meznarić, 1986, p. 72).

${ }^{\mathrm{xxx}}$ Among others, Milan Kundera, Gyorgy Konrad, and Czeslaw Miłosz.

xxxi Jurić Pahor (2012) offers a critical view on the imaginary of the Alps-Adria region as a historical unity with a common past. She stresses the selective (re)construction of the AlpsAdriatic cultural space for the needs and experiences of the contemporary Europe. 
${ }^{x \times x}$ Economic Relations between the EEC and Yugoslavia in the Light of the Future Cooperation Agreement Oral question (O-68/77) with debate, by Mr Bettiza, Mr Cifarelli, Mr Damseaux, Mr De Clercq, Mr Geurtsen, Mr Zywietz and Mr Bangemann to the Commission of the European Communities Brussels, 14 November 1977 (European Parliament, 370/77). In Radeljić, 2017a, p. 116.

\section{References}

Allcock, J. (2000). Explaining Yugoslavia. London: Hurst.

Abadan-Unat, N. (1993). Turkey: Late Entrant into the Europe's Work Force. In Kubat, D. (ed.), The Politics of Migration Policies. Settlement and Integration. The First World in the 1990s, (pp. 307-336). New York: Center for migration studies.

Arikan, H. (2003). Turkey and the EU: an Awkward Candidate for EU Membership?. Aldershot: Ashgate.

Baker, C. (2015). The Yugoslav Wars of the 1990s. London: Palgrave.

Baučić, I. (1973). Neka suvremena obilježja i problemi vanjskih migracija jugoslovenskih radnika [Some current characteristics and problems regarding external migration of Yugoslav workers], Sociologija, 15(2), 183-214.

Bock-Luna, B. (2005). The Past in Exile. Serbian Long-Distance Nationalism and Identity in the Wake of the Third Balkan War. Berlin: Lit.

Bucarelli, M. (2008). La “questione jugoslava” nella politica estera dell'Italia repubblicana (1945-1999) [The "Yugoslav question" in the foreign policy of the Republic of Italy (19451999)]. Rome: Aracne.

Brunnbauer, U. (2009). Labour Emigration from the Yugoslav Region from the late 19th Century until the End of Socialism: Continuities and Changes. In Brunnbauer, U. (ed.), Transnational Societies, Transterritorial Politics. Migrations in the (Post-)Yugoslav Region, 20th-21st Century, (pp. 17-49). Munich: Oldenbourg.

Calic, M.-J. (2011). The beginning of the end - The 1970s as a historical turning point in Yugoslavia”. In Calic, M.J., Neutatz, D., \& Obertrei, J. (eds.) The Crisis of Socialist Modernity, (pp. 66-86). Göttingen: Vandenhoeck and Ruprecht.

Chin, R. (2007). The Guest Worker Question in Postwar Germany. Cambridge: Cambridge University Press

Comte. E. (2018). The History of the European Migration Regime. Germany's Strategic Hegemony. Oxford-New York: Routledge.

Comte, E. (2015). Migration and regional interdependence in the Mediterranean, from the early 1980s to the mid 1990s. Journal of European Integration History, 21(1), 109-123.

Comte, E. (2012). European Regionalism and Migration Global Governance. Les Cahiers Irice, 9(1), 117-137. doi:10.3917/1ci.009.0117. 
Davidović, M. (1986). Uporedna analiza zapošljavanja jugoslovenskih radnika u zapadnoj Evropi i u SR Sloveniji [Comparative analysis of the employment of Yugoslav workers in Western Europe and in Slovenia]. Sociologija, 28, 325-346.

De Tapia, S. (2008). The Euro-Mediterranean Migration System and the Effects in Countries of Origin of Transfers of Funds. Strasbourg Cedex: Council of Europe.

Devetak, S. (1988). The Alpe-Adria as a multinational region. Slovene Studies, 10(1), 27-35.

Fielding, A. (1993). Migrants, Institutions and Politics: the Evolution of European Migration Policies. In King R. (ed.), Mass Migration in Europe. The Legacy and the Future (pp. 40-62). London: Belhaven Press.

Glaurdić J. (2011). The Hours of Europe. Western Powers and the Breakup of Yugoslavia. New Haven: Yale University Press.

Gow, J., \& Carmichael., C. (2010). Slovenia and the Slovenes. A Small State in the new Europe. London: Hurst.

Grilli, E. (1993). The European Community and the Developing Countries, Cambridge: Cambridge University Press.

Haberl, O. N. (1978). Die Abwanderung von Arbeitskräften aus Jugoslawien. Zur Problematik ihrer Auslandsbeschäftigung und Rückführung [The emigration of workers from Yugoslavia. On the problem of their employment abroad and their return]. Munich: Oldenbourg.

Hansen, R. (2003). Migration to Europe since 1945. Its History and its Lessons. The Political Quarterly, 74(1), 25-38. doi 10.1111/j.1467-923X.2003.00579.x .

Heršak, E. (1986). Promjene migracijske perspecktive s prijerom Italije [Changes in migration perspectives with a focus on Italy]. Unpublished master's thesis. University 'Edvard Kardelj', Ljubljana.

Hockenos, P. (2003). Homeland Calling. Exile Patriotism and the Balkan Wars. Ithaca, NY: Cornell University Press.

Horvat, B. (1976). The Yugoslav Economic System. The first labor-managed economy system in the making. New York: International Arts and Sciences.

Ivanović, V. (2012). Geburtstag pišeš normalno. Jugoslovenski gastarbajteri u Austriji i SR Nemačkoj 1965-1973 [Birthday is written as it is spoken. Yugoslav Gastarbeiter in Austria and FR Germany]. Belgrade: Institut za savremenu istoriju.

Jakovina, T. (2011). Treća strana hladnog rata [The third side of the Cold War]. Zagreb: Fraktura.

Jović, D. (2009). Yugoslavia. A State that Withered Away. West Lafayette, IN: Purdue University Press.

Jurić Pahor, M. (2012). Čezmejni in transkulturni imaginariji: Alpsko-Jadranski prostor v kontekstu njegovega zamišljanja in o(d)smišljanja [Cross-border transcultural imaginaries; the Alps-Adriatic space in the context of its ideation and (de)construction], Annales. Series. 
Historia et socologia, 22 409-424. Retrieved from http://zdjp.si/wpcontent/uploads/2015/10/ASHS_22-2012-2_Juric-Pahor.pdf .

King, R. (1993). European international migration 1945-90: a statistical and geographical overview (pp. 19-39). In King, R. (ed.), Mass Migration in Europe. The Legacy and the future, London: Belhaven Press.

King, R. (2001) The Mediterranean Passage: Migration and new cultural Encounters in Southern Europe. Liverpool: Liverpool University Press.

Klabjan, B. (2013). “Transnacionalne politike, nacionalna diplomacija?” Slovenci in delovna skupnost Alpe-Jadran 1978-1991 [“Transnational Politics, National Diplomacy?” The Slovenes in the working community Alpe-Adria 1978-1991]. Acta Histriae, 3, 409-426. Retrieved from http://zdjp.si/wp-content/uploads/2016/05/AH_21-2013-3_Klabjan.pdf .

Korać, M. (1981). Razlike u razvijenosti republika i pokrajina [Differences in the development of republics and autonomous provinces]. Naše Teme, 9, 1329-1346.

Kubat, D. (1993). Introduction to the First Edition. In Kubat D. (ed.), The Politics of Migration Policies. Settlement and Integration. The first World in the 1990s (pp. xi-xxiv). New York: Center for Migration Studies.

Kubat D., Mehrländer, U., \& Gehmacher., E. (eds.). (1979). The Politics of Migration Policies. The first World in the 1970s. New York: Center for Migration Studies.

Magnusson, K. (1987). The Serbian Reaction: Kosovo and Ethnic mobilization among the Serbs. Nordic Journal of Soviet and East European Studies 3, 3-30.

Malačič, J. (1989). Međurepubličke i vanjske migracije u Sloveniji od sredine 1950-ih godina - Ekonomski uzroci i posljedice [Intra-republic and external migration in Slovenia from the mid-1950s - Economic reasons and consequences]. Migracijske Teme, 4, 325-339.

Martin, C., \& D'Adrea Tyson, L. (1985). Can Titoism survive Tito? Economic problems and policy choices confronting Tito's successors. In Ramet, P. (ed.), Yugoslavia in the 1980s, (pp. 184-200). Boulder, Colorado: Westview.

Mesić M., \& Heršak, E. (1989). Evropa, integracija, i (Jugoslavenska) migracija [Europe, Integration, and (Yugoslav) migration]. Migracijske Teme, 1, 5-20.

Meznarić, S. (1986). "Bosanci”-A kuda idu Slovenci nedeljom? ["Bosnians" - Where are Slovenes going on Sundays?]. Belgrade: Filip Višnjić.

Meznarić, S. (1978). Imigracije radnika iz drugi jugoslavenskih republika u SR Sloveniju [Immigration of workers from other Yugoslav republics to the Federal Republic of Slovenia]. Sociologija, 2-3, 293-311.

Molnar, C. (2016). On the Move and putting down Roots. Transnationalism and Integration among Yugoslav Guest Workers in West Germany (p. 191-208). In: Coy, J., \& Poley, J., \& Schunka, A. (eds.), Migrations in the German Lands, 1500-2000, New York-Oxford: Berghahn.

Molnar, C. (2014). On the Move and putting down Roots. Transnationalism and Integration among Yugoslav Guest Workers in West Germany (pp. 191-208). In: Coy J., Poley J. \& Schunka A. (eds.), Migration in the German Lands (1500-2000). New York: Berghahn. 
Nejašmić, I. (1981). Povratak jugoslavenskih vanjskih migranata i njihovo ukjlučivanje u gospodarski i društveni život zemlje [The return of Yugoslav external migrants and their inclusion in the economic and social life of the country], special issue of Rasprave $o$ migracijama, 73.

Obadić, I. (2014). A troubled Relationship: Yugoslavia and the European Economic Community in Détente. European Review of History: Revue européenne d'histoire, 2, 329-342. doi: 10.1080/13507486.2014.888709.

OECD. (1988).The OECD and return migration, Note by the Secretariat (Seminar on returnees and their reintegration), Athens 10-12. 5.

Patterson, P. (2010). The East is Read. The End of Communism, Slovenian Exceptionalism, and the Independent Journalism of Mladina. East European Politics and Societies, 14(2), 411-459. doi:https://doi.org/10.1177/0888325400014002008 .

Patterson, P. (2003). On the Edge of Reason: The Boundaries of Balkanism in Slovenian, Austrian, and Italian Discourse. Slavic Review, 62(1) 110-141. doi: 10.2307/3090469 .

Petković, L. (1988). Problemi međunarodnih migracija radne snage s osvtom na Jugoslaviju [Problems of international labour migration with reference to Yugoslavia]. Belgrade: Naučna Knjiga.

Pleština, D. (1992). Regional Development in Communist Yugoslavia. Success, Failure, and Consequences. Boulder: Westview Press.

Prashad, V. (2007). The Darker Nations. A People's History of the Third World. New York: New Press.

Pušić, P. (1985). Situacija stranih radnika u SR Nemačkoj uz poseban osvrt na položaj i problematiku jugoslavenskih građana [The condition of foreign workers in FR Germany with a special focus on the position and problems of Yugoslav citizens]. Migracijske Teme, 1(1), $37-52$.

Radeljić, B. (2017b). Introduction: On Archives and Documents: Understanding the European Community-Yugoslav Relations through Primary Sources. In: Radeljić, B. (ed.), European Community -Yugoslav Relations. Debates and Documents that Mattered (19681992) (pp. 1-48). Bern: Peter Lang Publishing.

Radeljić, B. (2012). Europe and the Collapse of Yugoslavia. The Role of Non-State Actors and European Diplomacy. London: I.B. Tauris.

Ragazzi, F. (2009). The Croatian 'Diaspora Politics: Nationalism Unbound?. In Brunnbauer U. (ed.), Transnational Societies, Transterritorial Politics. Migrations in the (Post-)Yugoslav Region, 19th-21st Century, (pp. 145-167). Munich: Oldenbourg.

Ramet, S. (2005). Thinking about Yugoslavia. Scholarly Debates about the Yugoslav Breakup and the Wars in Bosnia and Kosovo. Cambridge: Cambridge University Press.

Ramet, S. (1999). Balkan Babel: the Disintegration of Yugoslavia from the Death of Tito to the War for Kosovo. Boulder, Colorado: Westview, third edition.

Rančić, M. (ed.). (1990) Pogledi na migracije stanovništva Jugoslavije [Views on the migrations of the population of Yugoslavia]. Belgrade: Centar za demografska istraživanja. 
Rubinstein, A. (1970). Yugoslavia and the Nonaligned World. Princeton: Princeton University Press.

Rusinow, D. (1978). The Yugoslav Experiment 1948-1974. Berkley and Los Angeles: University of California Press.

Samary, C. (1995). Yugoslavia Dismembered. (P. Drucker trans.). New York: Monthly Review Press.

Schierup, C. (1990). Migration, Socialism and the International Division of Labour. The Yugoslav Experience. Aldershot: Averbury.

Shoup, P. (2008). The Disintegration of Yugoslavia and Western Foreign Policy in the 1980s. In Cohen L., \& Dragović-Soso, J. (eds.), State Collapse in South-Eastern Europe: New Perspectives on Yugoslavia's Disintegration (pp. 333-364). West Lafayette, IN: Purdue University Press.

Skrbiš, Z. (2007). 'The First Europeans' Fantasy of Slovenian Venetologists: Emotions and Nationalist Imaginings. In Svašek M. (ed.), Postsocialism: Politics and Emotions in Central and Eastern Europe, (pp. 138-158). Oxford: Berghahn.

Skrbiš, Z. (1999). Long Distance Nationalism: Diasporas, Homelands, and Identities. Aldershot: Ashgate.

SOPEMI. (1981). Rasprave o Migracijama, 72.

Statistički godišnjak Jugoslavije [Statistical Yearbook of Yugoslavia]. (1983). Belgrade: Savezni zavod za statistiku.

Tanić, Ž. (1974). Seljaci na evropskim raskrnicama. Analiza ekonomska emigracija [Peasants at European crossroads. Analysis of economic emigration]. Belgrade: Centar za sociološka istraživanja.

Tapinos, P. (2000). Globalisation, Regional Integration, International Migration. International Social Sciences Journal 165, 297-306. doi: 10.1111/1468-2451.00258 .

Vedriš, M. (1978). Od devisnih ušteda do radnog mjesta u domovini [From foreign currency savings to a workplace in the homeland]. Special issue of Rasprave o Migracijama, 46. Vedriš, M. (1979). O ulozi i mogućem korištenju deviznih potencijala ostvarenih vanjskim migracijama [On the role and possible use of foreign exchange potentials created by external migrations]. Rasprave o Migracijama, 60, 70-78.

Veselinov, D. (1987). Sumrak seljaštva [The sun sets on the peasantry], Belgrade: Ekonomika.

Vuksanović, G., \& Tomić, D. (2011). Mešovita domaćinstva/gazdinstva i njihova uloga u uslovima ekonomske krize [Mixed households/farms and their role in the conditions of the economic crisis]. Društvo, Struktura, Promene. Tematski Zbornik, 178-197, Faculty of Philosophy: Novi Sad.

Westad, A. (2005). The Global Cold War. Third World Interventions and the Making of our Times. Cambridge. Cambridge University Press. 
Winterhagen, J. 2006. Vom 'Gastarbeiter' zum 'transnationalen' Modernisierer. Die Verwendung von Remittances am Beispiel des ehemaligen Jugoslawien, [From 'guest worker' to 'transnational' moderniser. The use of remittances using the example of the former Yugoslavia] Unpublished master thesis. Free University of Berlin, Berlin.

Woodward, S. (1995a). Balkan Tragedy. Chaos and Dissolution after the Cold War. Washington D.C.: Brookings Institution.

Woodward, S. (1995b). Socialist Unemployment. The political Economy of Yugoslavia 1945-1990. Princeton: Princeton University Press.

Zaccaria, B. (2016). The EEC's Yugoslav Cold War Policies in Europe 1968-1980. London: Palgrave MacMillan.

Zimmermann, W. (1987). Open Borders, Non Alignment and the Political Evolution of Yugoslavia. Princeton: Princeton University Press.

Published Document:

Radeljic, B. (ed.). (2017a). European Community - Yugoslav Relations: Debates and Documents that Mattered (1968-1992), Bern: Peter Lang Publishing.

Unpublished documents:

Archives of Yugoslavia, Belgrade - Collections 142/II (Socialist Alliance of Working People of Yugoslavia), 467 (Federal Bureau for Employment Affairs), 557 (Federal Committee for Employment).

The National Archives, London, Collection PREM (Prime Minister's Office Files), fasc. 19, doc. 1036, Record of a conversation between the prime minister and the chancellor of the Federal Republic of Germany at 1930 hours on 28 October in Bonn, 28 October 1982.

Table 1

Workers temporarily employed abroad and family members who resided abroad with them

1971

1981

\begin{tabular}{|c|c|c|c|c|}
\hline & $\begin{array}{l}\text { WORKERS } \\
\text { TEMPORARILY } \\
\text { EMPLOYED ABROAD }\end{array}$ & $\begin{array}{l}\text { FAMILY MEMBERS } \\
\text { ABROAD }\end{array}$ & $\begin{array}{l}\text { WORKERS } \\
\text { TEMPORARILY } \\
\text { EMPLOYED ABROAD }\end{array}$ & $\begin{array}{l}\text { FAMILY MEMBERS } \\
\text { ABROAD }\end{array}$ \\
\hline SFRJ & 671,908 & 91,818 & 625,069 & 249,899 \\
\hline $\begin{array}{l}\text { BOSNIA- } \\
\text { HERZEGOVINA }\end{array}$ & 137,351 & 9,468 & 133,902 & 49,038 \\
\hline MONTENEGRO & 7,829 & 3,228 & 9,781 & 9,036 \\
\hline CROATIA & 224,722 & 30,134 & 151,619 & 58,711 \\
\hline MACEDONIA & 54,433 & 13,655 & 57,966 & 42,960 \\
\hline
\end{tabular}




\begin{tabular}{l|lccc}
\hline SLOVENIA & 48,086 & 5,438 & 41,826 & 11,657 \\
SERBIA (ALL) & 199,487 & 29,895 & 229,975 & 78,471 \\
SERBIA PROPER & 114,581 & 18,809 & 152,932 & 50,489 \\
KOSOVO & 24,361 & 1,139 & 28,965 & 10,469 \\
VOJVODINA & 60,545 & 9,948 & 48,078 & 17,513
\end{tabular}

Source: Statistički godišnjak Jugoslavije $(1983,441)$. 